\title{
Morphology and taxonomy of Stephanodiscus vestibulis sp. nov. (Bacillariophyta)
}

\author{
H. Håkansson, E. C. Theriot and E. F. Stoermer
}

Håkansson, H., Theriot, E. C. \& Stoermer, E. F. 1986. Morphology and taxonomy of Stephanodiscus vestibulis sp. nov. (Bacillariophyta). - Nord. J. Bot. 6: 501-505. Copenhagen . ISSN 0107-055X

\begin{abstract}
A new species Stephanodiscus vestibulis is described from an eutrophic, hardwater habitat in western North America. Under the light microscope it resembles, and has perhaps been confused with, certain other small species of the genus. Structural features of the valve resolved by SEM, however, show that it is unique. The new species is particularly characterized by arch-like vestibules over the external openings of the marginal strutted processes. Other features include central and marginal strutted processes with three satellite pores, internally domed criba on the puncta and a single labiate process.
\end{abstract}

H. Hakkansson, Lab. of Quaternary Biology, Univ. of Lund, Tornavägen 13, S-223 63 Lund, Sweden. $-E$. C. Theriot and E. F. Stoermer, Great Lakes Research Division, Univ. of Michigan, Ann Arbor 48109, Michigan, USA.

\section{Introduction}

Small centric diatoms are abundant and ecologically important in many freshwater ecosystems. The occurrence and abundance of certain species has been concidered indicative of particular ecological conditions in limnological (e.g., Stoermer 1978) and paleolimnological (e.g., Battarbee 1979) studies. The potential usefulness of this approach has been limited, to a certain degree, by lack of taxonomic precision and confusion concerning the systematics and nomenclature of some widely distributed and ecologically important species. The true identities of the genus Stephanodiscus Ehrenb. have proven particularly difficult to resolve because several common species are polymorphic (Håkansson \& Stoermer 1984, Stoermer \& Hăkansson 1984, Theriot \& Stoermer 1984). The situation is further complicated by the fact that the formal nomenclature of some widely distributed taca has been frequently misconstrued (Hăkansson \& Locker 1981, Håkansson 1986).

In our recent investigations it has also become apparent that there are a number of apparently undescribed taxa in both Cyclostephanos Round and Stephanodiscus which might be confused with previously known species. In the following report we will describe and discuss the classification of one such taxon.

\section{Material and methods}

The material used in this investigation was collected from a locality locally known as "Lazy Lagoon" in Dickinson County, Iowa, USA. It is a circular, man-made, canal which is connected to Lake West Okoboji by a narrow channel on its eastern side. Lake West Okoboji is an eutrophic, hardwater lake which supports diatom blooms in the spring and fall and blue-green algal blooms during the summer (Bachmann \& Jones 1974). In addition to nutrient supply from the lake, Lazy Lagoon receives drainage from cottages and a road surrounding it, and its waters usually have higher nutrient and dissolved solids content than Lake Okoboji (Stoermer - unpubl. data).

The material used in the investigation was collected (by Håkansson) on 18 July 1979 with a $10 \mu \mathrm{m}$ mesh plankton net in Lazy Lagoon. The concentrated material was fixed in the field with 6-3-1 solution (Prescott

(C) NORDIC JOURNAL OF BOTANY

NORD. J. BOT. 6; 501-505. PHYCOL 060 
1962). The material was gently cleaned by treatment with $30 \% \mathrm{H}, \mathrm{O}$, (Håkansson 1984). For observations with light microscope (LM), subsamples of the cleaned material were strewn on cover glasses, air dried, and mounted in Naphrax. For scanning electron microscopy (SEM) subsamples of the cleaned material were strewn on cover glasses, which were air dried and then fixed to aluminum stubs with conductive paint. The preparations were then coated with gold in a Polar sputter coater.
Light microscope observations were made with a Zeiss Photomicroscope III furnished with an interference contrast optical system providing 1.40 numerical aperture (NA) and a Leitz Dialux 20 with standard optical system, providing 1.30 NA. Light micrographs were taken on the latter instrument with a Leitz Vario-Orthomat camera on Kodak Technical Pan Film No. 2415. SEM observations were made with an ISI MINISEM III and a ISI model DS-130, both operated at $15 \mathrm{kV}$. Mi-

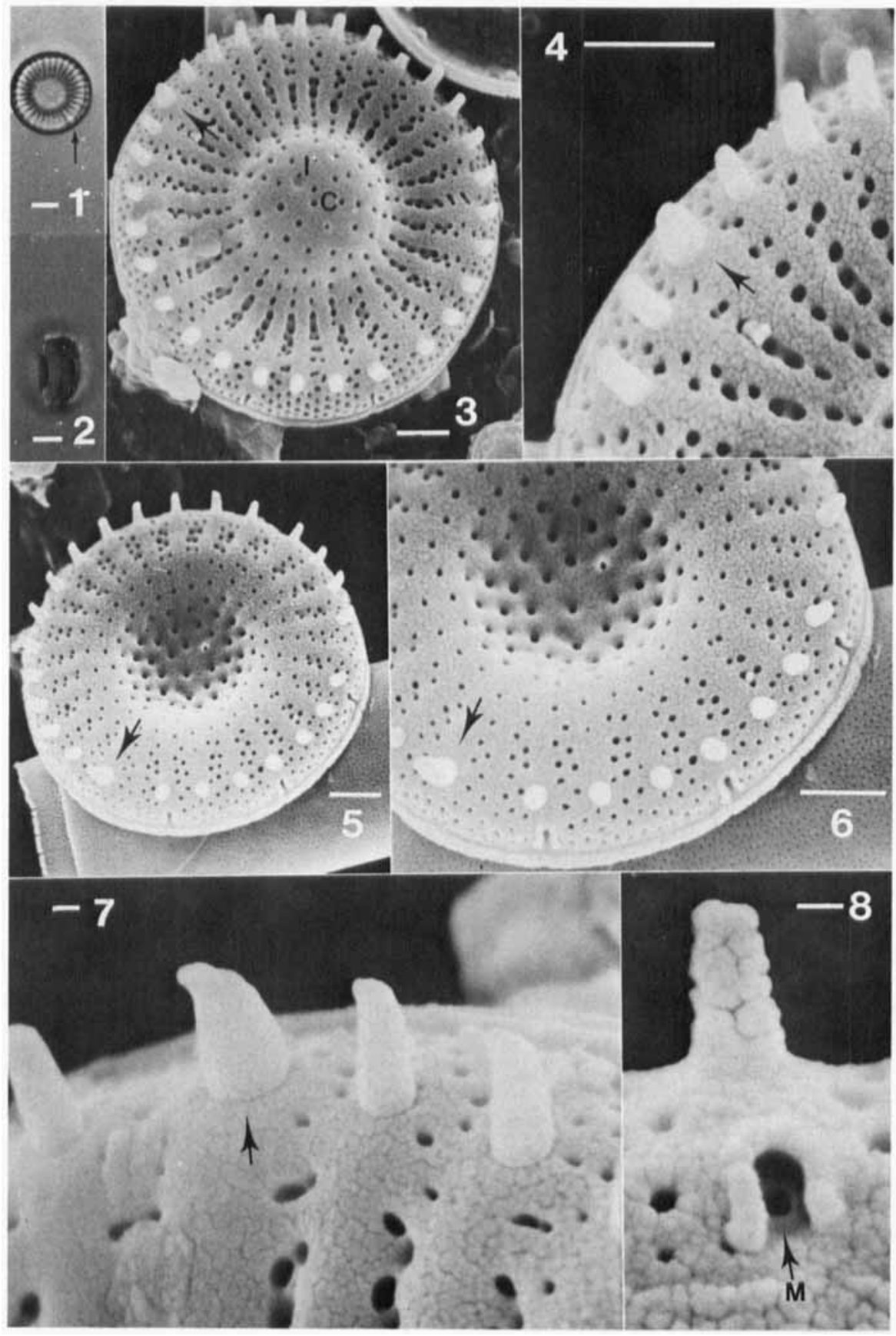

Figs 1-8. Stephanodiscus vestibulis. Arrows indicate position of labiate process. Figs 1-2. LM. Scale: $5 \mu \mathrm{m}$. - Fig. 1. Valve view. - Fig. 2. Girdle view. - Figs 3-8. SEM. Scale: 1 um, (Figs 3-6); $0.1 \mu \mathrm{m}$ (Figs 7-8). Fig. 3. Convex valve. Positions of external opening of the central process (below $\mathrm{C}$ ) and impression of external strutted process opening of the sibling valve (below I). Fig. 4. Higher magnification of same valve showing the position of external portion of the labiate process. - Fig. 5. External view of concave valve. - Fig. 6. Same valve at higher magnification. Fig. 7. Oblique top view of valve face/valve mantle junction, showing placement of spines and external portion of the labiate process. - Fig. 8. Oblique low view of the valve margin, showing a spine subtended by a "vestibule" with the external opening of a marginal strutted process (M). 
Figs 9-12. Stephanodiscus vestibulis. SEM. Scale: 1 um. - Fig. 9. Plane view of concave valve, showing position of central strutted process, marginal strutted processes, and labiate process. - Fig. 10. Oblique view of concave valve showing 3 struts on central and marginal processes. Fig. 11. Same specimen at higher magnification, showing satellite pores of the strutted processes and slit-like internal opening of labiate process. - Fig. 12 Oblique view, showing domed internal cribra and extensions of interfascicles onto valve mantle.

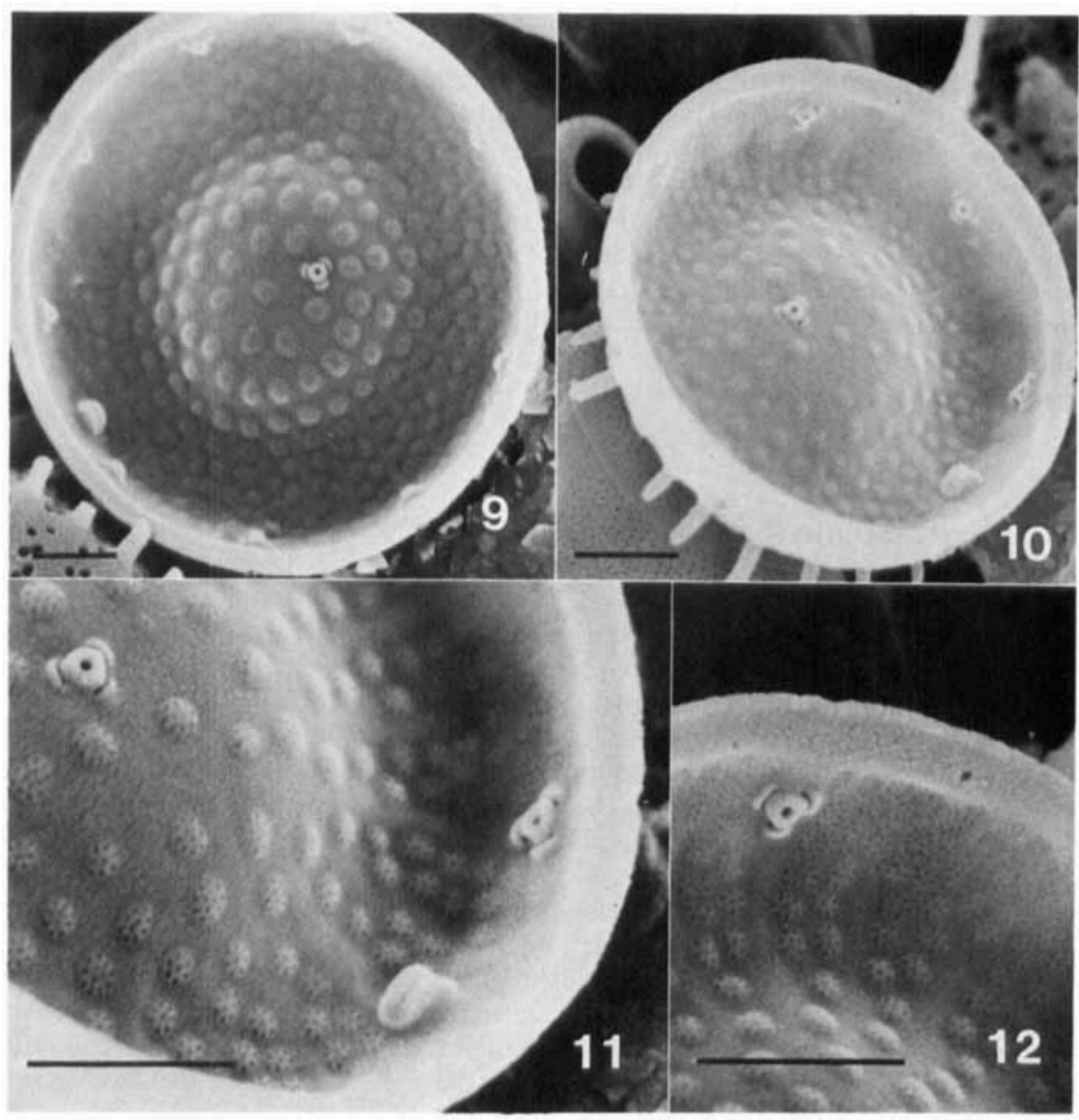

crographs were taken with the latter instrument using Polaroid PN 55 film.

\section{Results}

When observed under LM (Figs 1-2), specimens are circular in valve view with a strongly concave or convex central region. In our material valve diameter range from 4 to $11 \mu \mathrm{m}$, but auxospores or initial cells were not observed so the complete size range may be greater. The striae form broad fascicles near the valve face/valve mantle junction but quickly narrow and become disorganized by the beginning of the central elevation or depression. The fascicles are about $12-14$ in $10 \mu \mathrm{m}$ near the valve face/valve mantle junction and are separated by obviously thickened, hyaline interfascicles. In most valves the interfascicles appear to end in a spine near the valve face/valve mantle junction. A single central strutted process, slightly eccentric can occasionally be distinguished. The frustules are narrow in girdle view (Fig. 2) and are often observed in short colonies. Colony integrity is apparently maintained by juxtaposition of the alternately concave/convex valves, since no specially modified linking processes are obvious. One interfascicle is usually thicker than the others, recognizable with LM, and as discussed below, bears the labiate process.

These general characteristics are confirmed by SEM observations and the following additional characteristics can be resolved. In exterior views (Figs 3-8) the fasciculate organization of the puncta on the valve mantle is lost below the spine insertion. The spines are often slightly bent and broadened near their tips. In interior views (Figs 9-12) puncta have domed cribra. The interfascicles are slightly elevated in both internal (Fig. 11) and external (Figs 3-7) views. In external view (Figs 3, 5-6) the central strutted process is apparent as a slightly elevated opening, easily distinguised from the sunken central puncta. In some specimens a small depression, which is apparently the impression of the central strutted process of the sibling valve, occurs opposite it (Fig. 3). In internal view (Fig. 9), the central pore of the process is surrounded by three satellite pores. Internally, marginal strutted processes are essentially similar to central processes (Figs 10-12), and occur regularly on every third or fourth interfascicle. The external configuration of the marginal strutted processes is quite unusual (Figs 3, 5, 6, 8). A pore is enclosed by an arched 
"vestibule" or "porch" extending upward from the mantle edge of the valve (Fig. 8). A single labiate process occurs slightly below the level of spine insertion at the valve face/valve mantle junction (Figs 3-7). It is larger in base diameter than the spines and is more conical in shape; the interfascicle on which it occurs is usually thicker than the neighbouring interfascicles. Curiously in all specimens we have examined the external labiate process appears to be fully occluded (Fig. 7). In internal view (Figs 9-11) the labiate process is only slightly raised and its opening is nearly perpendicular to the interfascicle upon which it occurs.

\section{Discussion}

As far as we have been able to determine, this taxon has not been described in the literature. Based on characters visible under the SEM, we conclude that it is properly placed in the genus Stephanodiscus, as presently conceived. The characters it shared with other members of Stephanodiscus include puncta arranged in fascicles which are separated by interfascicles bearing spines which may be subtended by marginal strutted processes, with at least one labiate process. The morphological features characterizing Stephanodiscus and Cyclostephanos have been reviewed by Theriot and Kochiolek (in press). Their concept of Stephanodiscus included species with external extension of the labiate process and domed cribra on the mantle while their concept of Cyclostephanos included species without external extension of the labiate process, flat mantle cribra and internally raised interfascicles (costae). The generitype and other common members of Cyclostephanos such as $C$. dubius (Fricke) Round have internally raised interfascicles as does $S$. vestibulis (Håkansson 1976, Round 1982 ), but they are usually much more visually prominent. While we recognize that further generic revision of this group of centric diatoms may eventually prove necessary, it is our conclusion at present that this species is most appropriately classified under Stephanodis. cus.

In $\mathrm{LM}$ it resembles, and could be confused with, some of the other smaller members of the genus. When it is visible in LM, the single thickened interfascicle is a useful aid to identification. Stephanodiscus vestibulis is clearly distinguished from other presently known species, however, by the presence of a "vestibule" over the external openings of the marginal strutted processes as seen in SEM.

\section{Diagnosis}

Stephanodiscus vestibulis sp. nov.

Frustulia solitaria vel in filis brevissimis. Valvae disciformis, diametris 4-11 $\mu \mathrm{m}$ visis. Area centralis convexa aut concava. Puncta tholiformibus cribris, in area centrali dispersa vel ordinata in striis, versus marginem or- dinata in fasciculis duabus-quatuor striis. Fasciculi 12-14 $\mu \mathrm{m}$, inter costas radiantes. Costae extra et interne incrassatae. Spinae in annulo prope marginem. Fultoportulae tribus poris satelliticis. Fultoportulae 1 in area centrali; aliquot prope marginem quaque locata sub quaque tertia vel quatra spina. Fornix aperturam externum quaeque fultoportulae marginalis partim cinget, structura vestibulum simulans. Rimoportulae 1, latiora quam spina, aliquantum ulteris quam annulus spinarum locata, extra apparenter occlusa, interne pars labiacea ad costam prope faciei valvae cum palla valvae juncturam inserta.

Frustules solitary in very short filaments. Valves discshaped with diameters from 4 to $11 \mu \mathrm{m}$ observed. Central area convex or concave. Puncta having domeshaped cribra. Puncta in the central area disorganized or arranged in striae, arranged in fascicles of 2 to 4 striae towards the valve face/valve mantle junction. Fascicles $12-14$ in $\mu \mathrm{m}$, between radiating interfascicles. Interfascicles thickened internally and externally. Spines in a ring near the valve face/valve mantle junction. Strutted processes with three satellite pores. One strutted process in the central area; several on the mantle, each located beneath every third or fourth spine. The external opening of each marginal strutted process is partly surrounding by an arch, the structure porch-like or resembling a "vestibule". One labiate process, wider than the spine, located somewhat beyond the ring of spines, and apparently externally occluded, internally has the lip-like part inserted on an interfascicle near the juncture valve face/valve mantle.

Type: Slide No. A-G. C. 63786 in Diatom Herbarium, Academy of Natural Sciences of Philadelphia (Holotype). Isotype material in Håkansson collection Lund No. 134-138. Iconotype figure following Fig. 3. - Type Locality: Planktonic in a freshwater canal locally known as "Lazy Lagoon", Dickinson County, Iowa. Collected by H. Håkansson, 18 July 1979.

The epithet vestibulis refers to the characteristic "vestibules" covering external openings of the marginal strutted processes in this species.

Acknowledgements - This investigation was supported by NSF Grant No. BSR-84 12306. H. Håkansson's travel was supported by NFR Grant No. R-RA 4355-109. The material was collected during previous research at Iowa Lakeside Laboratory and $\mathbf{H}$. Hảkansson wishes to thank particularly Dr Richard Bovbjerg and Dr C. W. Reimer for support and courtesies extended during that visit.

\section{References}

Bachmann, R. W. \& Jones, J. R. 1974. Phosphorus inputs and algal blooms in Lakes. - Iowa State J. Research 49: 155 160 .

Battarbee, R. W. 1979. Diatoms in lake sediments. - In: Berglund, B. E. (ed.), Subproject B, Lake and Mire Environments. Vol. II. Specific Methods. International Geological Correlation Programme Project 158, Paleohydrological Changes in the Temperate Zone in the Last 15,000 Years. Dept. of Quaternary Geology, Lund, Sweden, pp. 177-225. 
Hăkansson, H. 1976. Die Struktur und Taxonomie einiger Stephanodiscus Arten aus eutrophen Seen Südschwedens. Bot. Notiser 129: 25-34.

- 1984. The recent diatom succession of Lake Havgårdssjön, south Sweden. - Proc. VII ${ }^{\text {th }}$ Internat. Diatom Symp. 1982, pp. 411-429. Otto Koeltz, Koenigstein.

- 1986. A taxonomic reappraisal of some Stephanodiscus species (Basillariophyta). - Brit. phycol. J. 21: 25-37.

- \& Locker, S. 1981. Stephanodiscus Ehrenberg 1846, a revision of the species described by Ehrenberg. - Nova Hedwigia, Beih. 35: 117-150

- \& Stoermer, E. F. 1984. Observations on the Type material of Stephanodiscus hantzschii Grunow in Cleve and Grunow. - Nova Hedwigia 39: 477-495.

Prescott, G. W. 1962. Algae of the Western Great Lakes area. - Wm. C. Brown Co., Dubuque.

Round, F. E. 1982. Cyclostephanos - a new genus within the Sceletonemaceae. - Arch. Protistenk. 124: 447-462.
Stoermer, E. F. 1978. Phytoplankton as indicators of water quality in the Laurentian Great Lakes. - Trans. Amer. Microsc. Soc. 97: 2-16.

- \& Håkansson, H. 1984. Stephanodiscus parvus: validation of an enigmatic and widely misconstrued taxon. -- Nova Hedwigia 39: 497-511.

Theriot, E. \& Stoermer, E. F. 1984. Principal components analysis of character variation in Stephanodiscus niagarae Ehrenb.: Morphological variation related to lake trophic status. - Proc. VII't Internat. Diatom Symp., 1982, pp. 97111. Otto Koeltz, Koenigstein.

- \& Kociolek, J. P. (In press.). Comments on classification of the freshwater Thalassiosiraceae (Bacillariophyta), with descriptions of two new species of Cyclostephanos. - J. Phycol. 